\title{
Faktor Yang Mempengaruhi Kebijakan Dividen Dimediasi Kepemilikan Manajerial Yang Tercatat Di BEI
}

\author{
Patricia Kurnikova Deli dan Ignatius Roni Setyawan \\ Program Studi Manajemen Fakultas Ekonomi, Universitas Tarumanagara, Jakarta \\ Email:deli.patricia@yahoo.com
}

\begin{abstract}
The study was conducted with the aim of proving that debt policy and price earning ratio affect dividend policy with managerial ownership as a mediating variable. In the study using a population of all companies included in manufacturing companies listed on the Indonesia Stock Exchange, using purposive sampling the total used in the study was 33 companies with secondary data taken from https://www.idx.co.id/. The result in this research prove that debt policy has a negative effect on dividend policy, while the price earning ratio has a positive effect on dividend policy. Then the presence of managerial ownership has a negative effect on debt policy research and price earnings ratio against dividend policy.
\end{abstract}

\section{Keyword : Debt Policy, Price Earnings Ratio, Dividend Policy, Managerial Ownership}

\begin{abstract}
Abstrak: Penelitian dilakukan dengan tujuan membuktikan bahwa kebijakan hutang dan price earning ratio berpengaruh kepada kebijakan dividen dengan kepemilikan manajerial sebagai variabel mediasi. Dalam penelitian menggunakan populasi seluruh perusahaan yang termasuk dalam perusahaan manufaktur yang tercatat di Bursa Efek Indonesia, dengan menggunakan purposive sampling maka total sampel yang digunakan dalam penelitian yaitu sebanyak 33 perusahaan dengan data sekunder yang diambil dari https://www.idx.co.id/ . Hasil dalam penelitian membuktikan bahwa kebijakan hutang berpengaruh negative terhadap kebijakan dividen, sedangkan price earning ratio berpengaruh positif terhadap kebijakan dividen. Kemudian dengan adanya kepemilikan manajerial berpengaruh negative dalam penelitian kebijakan hutang dan price earning ratio terhadap kebijakan dividen.
\end{abstract}

Kata Kunci : KebijakanHutang, Price Earning Ratio, Kebijakan dividen, Kepemilikan Manajerial

\section{LATAR BELAKANG}

Harapan dari mendirikan suatu perusahaan yakni terus berkembangnya perusahaan tersebut, namun hal tersebut membutuhkan dana yang tidak sedikit. Oleh karena itulah perusahaan dituntut untuk go-public. Untuk menjadi go-public, tidak sedikit masalah yang harus dihadapi suatu perusahaan. Ketika suatu perusahaan menjadi go-public, perusahaan dituntut untuk mensejahterakan para pemegang saham, dan disisi lain tetap harus menjaga kelangsungan perusahaan termasuk para agen (manajer), dan para pemangku kepentingan lainnya. Dalam rangka mensejahterakan pemegang saham dibagikanlah dividen.

Dividen ini akan mengurangi laba ditahan (sumber pendanaan internal) yang digunakan perusahaan untuk investasi dan kelangsungan keberadaannya, dan sebaliknya jika laba ditahan lebih besar tentu akan mengorbankan kesejahteraan pemegang saham, hal tersebutlah yang disebut dengan masalah keagenan yang mengakibatkan timbulnya agency cost karena kurangnya monitoring yang akan menentukan kebijakan dividen, sehingga perusahaan perlu menentukan kebijakan dividen yang tepat agar tidak memberatkan sebelah pihak saja. 
Kebijakan Deviden itu sendiri menjadi perhatian sangat penting terhadap para investor, khususnya para pemegang saham yang ingin berinvestasi dalam jangka panjang, sehingga banyak perusahaan berusaha untuk meningkatkan pembayaran dividen dari tahun ke tahun. Dividend payout ratio atau kebijakan dividen merupakan pembagian hasil keuntungan suatu perusahaan yang didapat dari pendapatan bersih perusahaan dan pendapatan tiap lembar saham yang dibayarkan secara relatif

Semakin tingginya tingkat hutang dalam suatu perusahaan maka akan memyebabkan menurunnya pembagian dividen dikarenakan sebagian besar keuntungan akan digunakan sebagai cadangan pelunasan hutang di masa yang akan datang. Sebaliknya, pada tingkat hutang yang rendah perusahaan akan membagikan dividen yang tinggi kepada pemegang saham dan laba perusahaan tersebut digunakan untuk kesejahteraan para investor. Peningkatan penggunaaan hutang itu sendiri akan menurunkan tingkat konflik antar manager dan investor sehingga pemegang saham tidak terlalu menuntut pembayaran dividen yang besar karena tingkat hutang yang dikeluarkan perusahaan relatif tinggi.

Kebijakan deviden juga menunjukkan persentase laba perusahaan yang dibayarkan kepada investor yang berupa dividen kas, apabila perusahaan membagikan laba sebagai deviden kas maka porsi untuk laba ditahan akan dikurangi, sebaliknya jika laba perusahaan digunakan untuk keperluan operasional perusahaan dalam jumlah besar maka deviden yang harusnya dibayarkan kepada investor akan menjadi lebih kecil. Oleh karena itu rasio pembayaran dividen menentukan berapa banyak jumlah laba yang dibagi dalam bentuk laba ditahan sebagai sumber pendanaan dan deviden kas. Adapun beberapa faktor yang mempengaruhi kebijakan deviden suatu perusahaan yaitu, kebutuhan dana perusahaan, likuiditas, kemampuan meminjam, dan keadaan pemegang saham

Dari berbagai ragam hasil temuan inilah motivasi penulis meneliti masalah ini, maka dari itu dilakukan penelitian yang berjudul “ Pengaruh Kebijakan Hutang dan Price Earning Ratio terhadap Kebijakan Dividen yang dimediasi oleh Kepemilikan Manajerial Pada Perusahaan Manufaktur yang Tercatat di BEI “.

\section{KAJIAN TEORI}

Agency Theory menjelaskan permasalahan yang terdapat pada suatu perusahaan dimana pihak yang memiliki kepentingan seperti pemilik perusahaan, penanam modal, kreditur dan juga manajer yang memiliki kepentingan yang berbeda. Manajer mempunyai tugas untuk mempertahankan keberlangsungan perusahaan dengan membuat kebijakan bagaimana pembagian dividen yang akan diberikan kepada investor dan juga untuk ditanam kembali menjadi laba ditahan yang mana pihak investor tidak terlalu setuju yang menimbulkan permasalahan dari penyatuan kepentingan ini yang biasa disebut agency conflict.

\section{Kebijakan Hutang}

Perusahaan pasti memiliki hutang dalam proses jalannya mencapai apa yang diinginkan, dimana hutang ini berasar dari kreditur, yang memiliki ketentuan waktu bagi perusahaan untuk melunasi kembali apa yang telah dipinjam dengan jangka waktu yang telah disepakati bersama. Apabila perusahaan tidak dapat membayarkan apa yang telah dipinjam dengan mengembalikan berupa uang tunai, perusahaan dapat mengembalikan kepada pihak yang bersangkutan berupa barang ataupun jasa dengan nilai yang sama serta sudah disetujui oleh pihak kreditur. 
Kebijakan hutang merupakan kebijakan yang diambil perusahaan untuk melakukan pembiayaan melalui utang (Kieso et al, 2007:96). Perusahaan dinilai beresiko apabila memiliki porsi utang yang besar dalam struktur modal, namun sebaliknya apabila perusahaan menggunakan utang kecil atau tidak sama sekali maka perusahaan dinilai tidak dapat memanfaatkan tambahan modal eksternal yang dapat meningkatkan operasional perusahaan (Hanafi, 2004:40)". (Sumanti, et. al, "Analisis Kepemilikan Manajerial, Kebijakan Hutang, dan Profitabilitas terhadap Kebijakan Dividend dan Nilai Perusahaan pada Perusahaan property \& real estate yang Terdaftar di BEI", 2015, Vol 3, No 1, Hal. 1143).

\section{Price Earning Ratio}

Price Earning Ratio merupakan teknik analisis fundamental yang menggunakan rasio antara harga saham itu sendiri terhadap laba per saham yang digunakan untuk mengetahui seberapa besar jumlah yang rela kita bayarkan untuk setiap laba yang dicatat dan seberapa lama waktu yang dibutuhkan agar keuntungan perusahaan kembali, apabila rasio semakin tinggi maka kinerja dalam perusahaan dapat dikatakan semakin baik tetapi jika rasio terlalu tinggi dapat dikatakan harga yang ditawarkan tidak rasional. Dalam hal ini, price earning ratio juga dapat digunakan untuk membuktikan apakah investasi yang dilakukan menguntungkan atau merugikan bagi penanam modal di suatu perusahaan.

Dalam hal ini price earning ratio merupakan sarana bagi investor untuk mengetahui bagaimana potensi jalannya suatu perusahaan di masa yang akan datang. Namun disaat nilai suatu laba negative, price earning ratio tidak akan ada artinya dan berubah secara signifikan.

\section{Kepemilikan Manajerial}

Kepemilikan manajerial merupakan kepemilikan saham biasa yang dimiliki oleh direksi dan komisaris yang dimana dalam laporan keuangan ditampilkan besaran kepemilikan sangat berpengaruh terhadap kinerja manajemen dalam suatu perusahaan.

Machmud dan Djakman (2008) mengatakan bahwa kepemilikan manajerial merupakan proporsi kepemilikan manajamen yang secara aktif ikut dalam mengambil keputusan dalam perusahaan. Kepemilikan manajerial mampu mengurangi masalah keagenan dalam perusahaan dengan mengimbangkan kepentingan-kepentingan manajer dengan pemegang saham dalam perusahaan tersebut.

\section{Kebijakan Dividen}

Dividen merupakan keuntungan yang dibagikan kepada pemegang saham berdasarkan proporsi saham yang mereka miliki dalam perusahaan tersebut. Besar kecilnya proporsi dividen yang diterima dilihat dari berbagai acuan yang dirundingkan para pemegang saham melalui Rapat Umum Pemegang Saham (RUPS).

"Kebijakan dividen menurut Agus (2001:281) adalah keputusan apakah laba yang diperoleh perusahaan akan dibagikan kepada pemegang saham sebagai dividen atau akan ditahan dalam bentuk laba ditahan guna pembiayaan investasi di masa datang. Apabila perusahaan memilih untuk membagikan laba sebagai dividen, maka akan mengurangi laba yang ditahan". (Isticharoh, et. al, "Pengaruh Kepemilikan Manajerial, Kebijakan Hutang, dan Profitabilitas terhadap Kebijakan Dividen”, 2016, Hal. 3 ). 
Laba bersih perusahaan akan berdampak berupa peningkatan saldo laba (retained earnings) perusahaan. Apabila saldo laba didistribusikan kepada pemegang saham maka saldo laba akan berkurang sebesar nilai yang didistribusikan tersebut.

Berdasarkan uraian diatas maka hipotesis

H1 : Kebijakan Hutang memiliki pengaruh negatif terhadap Kebijakan Dividen

$\mathrm{H}_{2}$ : Price Earning Ratio memiliki pengaruh positif terhadap Kebijakan Dividen

H3 : Kebijakan Hutang memiliki pengaruh negative terhadap Kepemilikan Manajerial

$\mathrm{H}_{4}$ : Price Earning Ratio memiliki pengaruh positif terhadap Kepemilikan Manajerial

$\mathrm{H}_{5}$ : Kebijakan Hutang memiliki pengaruh negative terhadap Kebijakan Dividen yang dimediasi oleh Kepemilikan Manajerial

$\mathrm{H}_{6}$ : Price Earning Ratio memiliki pengaruh positif terhadap Kebijakan Dividen yang dimediasi oleh Kepemilikan Manajerial

\section{METODOLOGI}

Desain penelitian ini adalah penelitan deskriptif . Deskriptif adalah dimana data dalam penelitian tidak ada yang dimanipulasi. Dalam penelitian ini menggunakan variabel intervening. Variabel dependen yaitu Kebijakan Dividen dan variabel independen yaitu Kebijakan Hutang dan Price Earning Ratio. Sedangkan variabel intervening (mediasi) yang digunakan ialah Kepemilikan Manajerial. Dalam penelitian ini menggunakan teknik pemilihan sampel non probability sampling dengan total sampel yang digunakan sebanyak 33 perusahaan. Pada penelitian ini menggunakan perusahaan manufaktur yang tercatat di Bursa Efek Indonesia dengan menggunakan periode 2017.Dalam penelitian ini menggunakan metode analisis yaitu perangkat aplikasi SmartPLS 3.0 yang mengatakan bahwa data harus terdistribusi normal secara multivariate dan tidak terdapat masalah multikolonieritas antar variabel (Ghozali dan Latan, 2014 : 5).

\section{HASIL ANALISIS DATA}

Pada gambar 1 menunjukan telah dilakukan analisis validitas dengan hasil analisis loading factor, nilai loading factor lebih besar dari 0,6 (Hair, Ringle, and Sarstedt 2011). Sementara untuk analisis reliabilitas pada Tabel 1 dilakukan dengan melihat nilai cronbach's alpha atau bisa melihat nilai composite reliability. Nilai yang disarankan untuk kriteria ini > 0,7(Hair et al. 2011), pengujian hipotesis juga dilakukan dengan menguji nilai T statistik dari penelitian. Dalam uji ini kriteria untuk diterima sebuah hipotesis yang di ajukan dalam penelitian pada tabel 2 adalah nilai T statistik harus lebih besar sama dengan 1,96 (Ghozali dan Latan, 2014: 77).

Gambar 1. Hasil Nilai Loading Factor

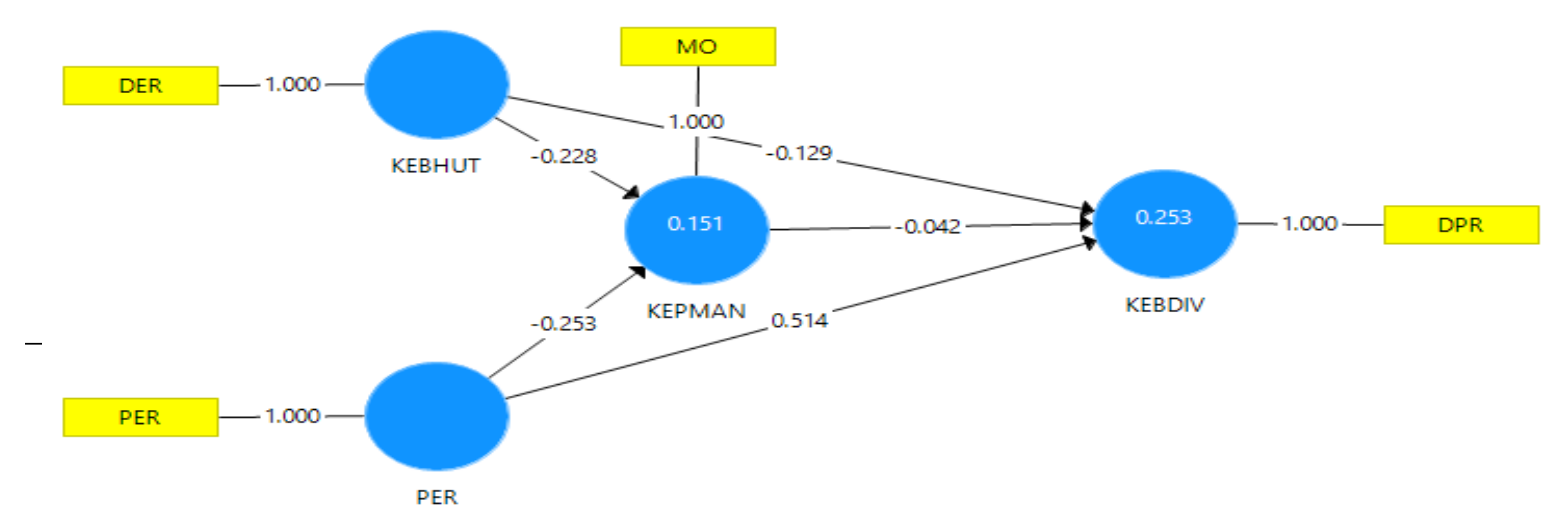


Penelitian ini dikatakan reliabel apabila nilai cronbach's alpha atau bisa melihat nilai composite reliability > 0,7(Hair et al. 2011)

Tabel 1. Uji Realibilitas

\begin{tabular}{|l|c|c|c|}
\hline & Cronbach's Alpha & rho_A & Composite Reliability \\
\hline Kebijakan Hutang & 1.000 & 1.000 & 1.000 \\
\hline Price Earning Ratio & 1.000 & 1.000 & 1.000 \\
\hline Kebijakan Dividen & 1.000 & 1.000 & 1.000 \\
\hline Kepemilikan Manajerial & 1.000 & 1.000 & 1.000 \\
\hline
\end{tabular}

hipotesis penelitian ini akan dinyatakan signifikan apabila variabel tersebut memiliki nilai t-statistics > 1,96 (Ghozali dan Latan, 2014: 77). Hasil analisis data secara singkat tertera pada tabel 2 sebagai berikut:

Tabel 2. Hasil Pengujian Hipotesis

\begin{tabular}{|l|c|c|c|c|c|}
\hline & $\begin{array}{c}\text { Original } \\
\text { Sample (O) }\end{array}$ & $\begin{array}{c}\text { Sample } \\
\text { Mean (M) }\end{array}$ & $\begin{array}{c}\text { Standard } \\
\text { Deviation } \\
(\text { STDEV) }\end{array}$ & $\begin{array}{c}\text { T Statistic } \\
(\mid \text { O/STDEV })\end{array}$ & P Values \\
\hline $\mathrm{X}_{1} \rightarrow \mathrm{Y}$ & -0.129 & -0.133 & 0.079 & 1.629 & 0.104 \\
\hline $\mathrm{X}_{2} \rightarrow \mathrm{Y}$ & 0.514 & 0.519 & 0.127 & 4.042 & 0.000 \\
\hline $\mathrm{X}_{1} \rightarrow \mathrm{M}$ & -0.228 & -0.234 & 0.104 & 2.189 & 0.029 \\
\hline $\mathrm{X}_{2} \rightarrow \mathrm{M}$ & -0.253 & -0.258 & 0.092 & 2.758 & 0.006 \\
\hline $\mathrm{X}_{1} \rightarrow \mathrm{M} \rightarrow \mathrm{Y}$ & 0.010 & 0.013 & 0.021 & 0.463 & 0.644 \\
\hline $\mathrm{X}_{2} \rightarrow \mathrm{M} \rightarrow \mathrm{Y}$ & 0.011 & 0.010 & 0.021 & 0.512 & 0.609 \\
\hline
\end{tabular}

\section{DISKUSI}

Bedasarkan Gambar 1 menunjukkan hasil uji convergent validity dengan melihat nilai loading factor. Variabel akan dinyatakan valid apabila nilai koefisien convergent validity lebih besar dari 0,7. Berdasarkan variable yang diteliti yaitu Kebijakan Hutang, Price Earning Ratio, Kepemilikan Manajerial, dan Kebijakan Dividen.

Pada tabel 1 menunjukkan menunjukkan nilai Cronbach's Alpha pada variable Kebijakan Hutang di atas 0,7, hal ini menunjukkan bahwa DER dinyatakan reliabel, PER (Price Earning Ratio), MO (Kepemilikan Manajerial), dan DPR (Kebijakan Hutang) nilai Cronbach's Alpha dan Composite Reliability diatas 0,7. 
Pada pengujian hipotesis pertama (H1) menunjukkan nilai original sampel variabel kebijakan hutang terhadap kebijakan dividen sebesar -0.129, artinya variabel kebijakan hutang mempunyai pengaruh positif terhadap variabel kebijakan dividen. Dimana terdapat pengaruh variabel kebijakan hutang terhadap kebijakan dividen tidak signifikan dengan nilai T- statistic sebesar 1.629 dan P-values sebesar 0.104, ini artinya hipotesis pertama diterima.

Pada pengujian $\mathrm{H} 2$, nilai original sampel $(\mathrm{O})$ sebesar 0.514 yang menunjukkan bahwa arah hubungan antara price earning ratio atas kebijakan dividen positif dengan nilai tstatistik sebesar 4.042 serta nilai p-values sebesar $0.000(<0.05)$, dapat disimpulkan path coefficient antara price earning ratio dengan kebijakan dividen memiliki pengaruh yang positif dan signifikan sehingga $\mathrm{H}_{2}$ diterima.

Pada pengujian $\mathrm{H} 3$, nilai original sampel $(\mathrm{O})$ sebesar -0.228 yang menunjukkan bahwa arah hubungan antara kebijakan hutang atas kepemilikan manajerial negative dengan nilai t-statistik sebesar 2.189 (>1.96) serta nilai p-values sebesar $0.029 \quad(<0.05)$, dapat disimpulkan path coefficient antara kebijakan hutang dengan kepemilikan manajerial memiliki pengaruh yang negative dan signifikan sehingga $\mathrm{H}_{3}$ tidak diterima.

Pada pengujian $\mathrm{H} 4$, nilai original sampel $(\mathrm{O})$ sebesar -0.253 yang menunjukkan bahwa arah hubungan antara price earning ratio atas kepemilikan manajerial negative dengan nilai t-statistik sebesar $2.758(>1.96)$ serta nilai p-values sebesar $0.006(>0.05)$, dapat disimpulkan path coefficient antara price earning ratio dengan kepemilikan manajerial memiliki prediktor yang negative dan tidak signifikan $\mathrm{H}_{4}$ tidak diterima.

Pada pengujian H5, nilai original sampel $(\mathrm{O})$ pada indirect effect ialah sebesar 0.010 yang menunjukkan tidak adanya peningkatan dengan adanya kepemilikan manajerial sebagai variabel intervening. Kemudian dengan nilai t-statistik sebesar $0.463(<1.96)$ dan nilai $p$-values sebesar 0.644 . Pada direct effect nilai $p$-values sebesar 0.433 yang kemudian pada indirect effect nilai p-values menjadi sebesar 0.161 yang menunjukkan adanya efek partial control, dapat disimpulkan path coefficient antara kebijakan hutang dengan kebijakan dividen memiliki pengaruh yang negative dan tidak signifikan dengan adanya kepemilikan manajerial sebagai variabel intervening sehingga $\mathrm{H}_{5}$ tidak diterima.

Pada pengujian H6, nilai original sampel $(\mathrm{O})$ pada indirect effect ialah sebesar 0.011 yang menunjukkan adanya penurunan dengan adanya kepemilikan manajerial sebagai variabel intervening. Kemudian dengan nilai t-statistik sebesar 0.512 dan nilai p-values sebesar 0.609 yang menunjukkan adanya efek partial control, dapat disimpulkan path coefficient antara price earning ratio dengan kebijakan dividen memiliki pengaruh yang negative dan tidak signifikan dengan adanya kepemilikan manajerial sebagai variabel intervening sehingga $\mathrm{H}_{6}$ tidak diterima.

\section{PENUTUP}

Berdasarkan hasil pengujian pada penelitian ini menunjukkan bahwa kebijakan hutang mempunyai pengaruh tidak signifikan terhadap kebijakan dividen dengan ada maupun tidak kepemilikan manajerial sebagai variable mediasi. Sedangkan price earning ratio memiliki pengaruh signifikan terhadap kebijakan dividen namun dengan adanya mediasi kepemilikan manajerial menjadi tidak signifikan. Hal ini terjadi apabila perusahaan ingin tetap maju keberlangsungannya maka dari itu manajer harus dapat menentukan berapa besar proporsi untuk keberlangsungan perusahaan dan proporsi untuk dibagikan kepada para investor dengan penjualan harga saham perusahaan yang baik serta diawasi oleh komisaris maupun direksi dalam perusahaan. Untuk penelitian berikutnya disarankan untuk 
menambah variabel yang mempengaruh kebijakan dividen serta memperbanyak sampel penelitian.

\section{DAFTAR PUSTAKA}

Andriani, M. N. F., \& Ardini, L. (2016). "Pengaruh Kebijakan Utang, Struktur Kepemilikan, dan Free Cash Flow terhadap Kebijakan Dividen”. Jurnal Ilmu dan Riset Akuntansi. Vol 5, No 8.

Arko, A. C., Abor J., Charles K.D., Adjasi, \& Amidu, M. (2014). "What influence dividend decisions of firms in Sub-Saharan African?". Journal of Accounting in Emerging Economies. Vol. 4 Issue: 1. pp.57-78. https://doi.org/10.1108/JAEE-122011-0053

Bansaleng, R. D. V., Tommy, P., \& Saerang, I. S. (2014). “Kebijakan Hutang, Struktur Kepemilikan dan Profitabilitas terhadap Kebijakan Dividen pada Perusaahaan Food \& Beverage di Bursa Efek Indonesia”. Jurnal EMBA. Vol.2 No.3, 819s.

Brigham, F. Eugene, dan J.F. Houston. (2005). Fundamentals of Financial Management. $10^{\text {th }}$ ed. Florida : The Dryen Press

Bungin, B. 2004. Metode Penelitian Kuantitatif. PT. Prenada Media. Jakarta.

Dajan, A. (2000). Pengantar Metode Statistik , Jilid I. LP3ES, Jakarta. Hal. 407-408.

Fahmi, Irham. (2013). Pengantar Manajemen Keuangan Teori dan Soal Jawaban. Cetakan Kedua, Bandung.

Firmanda, R., Kharis R., \& Oemar, A. 2015.“ Pengaruh Kepemilikan Manajerial, Kepemilikan Institusional, Kebijakan Hutang, Profitabilitas, Ukuran Perusahaan, dan Cash Position Terhadap Kebijakan Dividen. Journal Of Accounting. Vol.1 No.1.

Garson, G.D. (2016). Partial Least Square : Regression \& Structural Equation Model, $2016^{\text {th }}$ Ed. School of Public \& International Affairs North Carolina State University www.statisticalassociates.com

Gautama, B. P., \& Haryat, Y. (2014). "Pengaruh Struktur Kepemilikan dan Kebijakan Hutang terhadap Kebijakan Dividen pada Subsektor Konstruksi dan Bangunan yang tercatat di BEI". Vol 3, No 2.

Ghozali, I. (2001) Aplikasi Analisis Multivariate Dengan Program SPSS. Semarang: Badan Peneliti Universitas Diponegoro.

Ismiyanti, F., \& Mamduh. 2003. Kepemilikan Manajerial, Kepemilikan Insitusional, Risiko, Kebijakan Hutang dan Kebijakan Dividen: Analisis Persamaan Simultan. Simposium Nasional Akuntansi IV. 260-277.

Isticharoh, R.R. (2016). "Pengaruh Kepemilikan Manajerial, Kebijakan Hutang, dan Profitabilitas terhadap Kebijakan Dividen”. http://eprints.perbanas.ac.id/567/1/ARTIKEL\%20ILMIAH.pdf

Jayanti, I. S. D., \& Puspitasari, A. F. (2017). "Struktur Kepemilikan dan Kebijakan Dividen pada Perusahaan Manufaktur di Indonesia". The Indonesian Journal of Applied Business. Vol 1, No 1 